\title{
Pengaruh UU ITE Terhadap Kebebasan Berekspresi Di Media Sosial
}

\author{
Vonny Kristanti Kusumo ${ }^{1}$, Ie Lien Risey Junia ${ }^{2}$, Yuwono Prianto ${ }^{3}$ dan Tatang Ruchimat ${ }^{4}$ \\ ${ }^{1}$ Fakultas Hukum, Universitas Tarumanegara Jakarta \\ Surel: vonny.205210035@stu.untar.ac.id \\ ${ }^{2}$ Fakultas Hukum, Universitas Tarumanegara Jakarta \\ Surel: ielien.205210040@stu.untar.ac.id \\ ${ }^{3}$ Fakultas Hukum, Universitas Tarumanegara Jakarta \\ Surel:_yuwonop@fh.untar.ac.id \\ ${ }^{4}$ Fakultas Hukum, Universitas Tarumanegara Jakarta \\ Surel: tatangruchimat1@gmail.com
}

\begin{abstract}
In this sophisticated era, in the digital era, it is very easy for people to express opinions, express opinions, complain, share stories and experiences, or other things that they want to share with the public on social media. However, with the freedom of expression, there are often many violations that occur related to the Information and Electronic Transaction Law (hereinafter referred to as the "UU ITE"). So then people tend to have a fear of expressing themselves to the public on social media, due to ignorance and ignorance of the community towards the ITE Law. The ITE Law itself has two perspectives in the eyes of the public, some are looking at it from a positive point of view and some are looking at it from a negative point of view with the existence of this ITE Law. By using normative legal research methods, the sources used are secondary data. This research method is a library research method which is carried out by collecting legal materials through library studies and is guided by primary legal materials and secondary legal materials, and this research uses a statute approach. The purpose of this paper is to convey information about what things must be considered in using social media, how the influence of the news that the public conveys on social media in order to express themselves and how to use social media wisely, so that with this ITE Law does not make people worry about expressing themselves in any form on social media. So that in the future people can become wise and responsible users of social media..
\end{abstract}

Keywords: Freedom of Expression, Social Media, The ITE Law, Society.

\begin{abstract}
ABSTRAK
Pada zaman yang canggih ini, di era digital, masyarakat sangat mudah untuk menyampaikan opini, mengemukakan pendapat, berkeluh kesah, berbagi cerita dan pengalaman, atau hal-hal lainnya yang ingin dibagikan kepada publik di media sosial. Namun dengan adanya kebebasan berekspresi tersebut, sering dijumpai banyak pelanggaran yang terjadi berhubungan dengan UU Informasi dan Transaksi Elektronik (selanjutnya akan disebut "UU ITE"). Sehingga kemudian masyarakat cenderung memiliki rasa takut untuk mengekspresikan diri pada publik di media sosial, dikarenakan ketidaktahuan dan ketidakmengertian masyarakat terhadap UU ITE. UU ITE sendiri memiliki dua perspektif di mata masyarakat, ada yang melihat dari sudut pandang positif dan ada juga yang melihat dari sudut pandang negatif dengan adanya UU ITE ini. Dengan memakai metode penelitian hukum normatif, dan sumber yang digunakan adalah data sekunder. Metode Penelitian ini adalah metode penelitian kepustakaan yang dilakukan dengan cara pengumpulan bahan hukum melalui studi kepustakaan dan berpedoman pada bahan hukum primer serta bahan hukum sekunder, dan penelitian ini memakai pendekatan per UU (statute approach). Yang dimaksud dari penulisan ini yaitu untuk menyampaikan informasi mengenai hal-hal apa yang harus diperhatikan dalam memakai media sosial, bagaimana pengaruh dari pemberitaan yang masyarakat sampaikan pada media sosial dalam rangka mengekspresikan dirinya dan bagaimana menggunakan media sosial dengan bijak, sehingga dengan adanya UU ITE ini tidak membuat masyarakat menjadi khawatir untuk mengekspresikan diri dalam bentuk apapun di media sosial. Sehingga kedepannya masyarakat bisa menjadi pengguna media sosial yang bijak dan bertanggung jawab.
\end{abstract}

Kata Kunci : Masyarakat, Media Sosial, Kebebasan Berekspresi, UU ITE.

\section{PENDAHULUAN}

\section{Latar Belakang}

Di era digital sekarang, masyarakat menjadi sangat dimudahkan dengan adanya teknologiteknologi digital yang dapat menjangkau seluruh lapisan masyarakat. Masyarakat bisa dengan 
mudahnya menyampaikan opini, mengemukakan pendapat, berkeluh kesah, berbagi cerita dan pengalaman, atau hal-hal lainnya yang ingin dibagikan kepada publik di media sosial.

Namun dengan adanya kebebasan berekspresi tersebut, sering dijumpai banyak pelanggaran yang terkait dengan UU ITE, dikarenakan ketidaktahuan dan ketidakmengertian masyarakat terhadap UU ITE tersebut. Setelah banyaknya pelanggaran yang ditindak berdasarkan UU ITE, sekarang ini masyarakat menjadi takut dalam mengekspresikan dirinya di media sosial. Sehingga masyarakat merasa Hak Asasi dalam berpendapat dikekang oleh regulasi.

Pengertian Masyarakat menurut KBBI yaitu, sekumpulan manusia dengan kebudayaan yang sama. Berekspresi dengan cara mengeluarkan pendapat dan opini, membagikan cerita dan atau pengalaman, berkeluh kesah termasuk kedalam Ps. 1 No. 39 Thn 1999 HAMyang menyebutkan, "Hak Asasi Manusia adalah seperangkat hak yang melekat pada hakekat dan keberadaan manusia sebagai makhluk Tuhan Yang Maha Esa dan merupakan anugerahNya dan wajib dihormati, dijunjung tinggi dan dilindungi oleh negara, hukum, pemerintah, dan setiap orang demi kehormatan serta perlindungan harkat dan martabat manusia."

Ekspresi yang disampaikan tersebut bisa disalurkan lewat berbagai media, salah satunya yang paling mudah dijangkau dan digunakan adalah menggunakan media sosial untuk menyalurkan kebebasan berekspresi masyarakat.

Berikut adalah pengertian medsos dari para ahli :

1. Lisa Buyer mendefinisikan "media sosial sebagai wujud dari hubungan masyarakat yang paling transparan, menarik dan terkini atau up to date".

2. Sam Decker yang juga memberikan pendapatnya berbentuk gagasan berupa definisi media sosial yaitu suatu konten interaksi yang dibuat oleh individu, dengan individu yang lainnya.

3. Henderi, M.Yusup, dan Yuliana.I.Graba menyebutkan arti dari medsos yaitu "situs jaringan sosial contohnya layanan berbasis web yang memberikan kemungkinan bagi setiap individu untuk membangun profil publik ataupun non publik dalam sistem yang terbatas, daftar pengguna lain yaitu dengan siapa mereka berhubungan, dan melihat serta menelusuri daftar koneksi mereka yang dibuat oleh orang lain dengan sistem tertentu".

Dampak positif Medsos :

1. Lebih Cepat untuk mendapatkan berita yang up to date, baik dari dalam atau luar negeri.

2. Sebagai wadah untuk melakukan promosi dengan baik serta murah, dan membangun jiwa entrepreneurship mulai saat ini.

3. Menyiapkan tempat untuk berpendapat. Pemakaian media sosial juga sering digunakan oleh tokoh agama, motivator, dan ulama.

4. Mudah beradaptasi dan bersosialisasi dengan memperbanyak teman. Media sosial juga bisa menggambarkan sebuah pertemanan bila seseorang malu berteman di dunia nyata.

5. Sebuah media komunikasi yang mudah, cepat serta efisien.

6. Media tanpa batasan, pengguna bisa melakukan apa saja sesuai dengan kreativitasnya, menyampaikan pemikiran, gagasan, opini dan lainnya sesuai dengan kapasitas kemampuannya.

7. Membuka pandangan serta pengetahuan. Belum lama ini terdapat akun media sosial yang membagikan pandangan serta pengetahuan yang dapat mempengaruhi cara berpikir sesorang.

8. Tempat berbagi juga penyimpanan kegiatan sehari-hari (Sutarjo, Adisusila, 2013).

Dampak negatif media sosial :

1. Individual dan egoisme (sudah cukup berinterkasi di medsos, maka tidak perlu berinteraksi secara langsung).

2. Kurangnya komunikasi di dunia nyata. 
3. Bahaya kejahatan bahaya penipuan.

4. Tidak semua pengguna bersikap sopan.

5. Pornografi, penyebarannya secara luas di medsos memberikan dampak yang negatif yang tidak bermoral.

6. Prostitusi. Medsos juga dijadikan sarana untuk mendapatkan informasi tempat-tempat prostitusi.

7. Wadah penyaluran informasi paling efektif dan efisien, sehingga sangat mudah menyebarkan berita-berita bohong (hoax).

Ps. 19 Deklarasi Universal HAM atau Universal Declaration of Human Rights dikatakan bahwa setiap orang bebas berpendapat; dan juga bebas menganut pendapat tanpa gangguan. Serta mencari, juga menyampaikan keterangan atau penjelasan berpendapat dengan cara apa pun dan tidak memandang batas-batas.

Ps. 28F UUD 1945 perubahan kedua diresmikan pada bulan Agustus 2020, mengatakan "Setiap orang berhak untuk berkomunikasi dan memperoleh informasi untuk mengembangkan pribadi dan lingkungan sosialnya, serta berhak untuk mencari, memperoleh, memiliki, menyimpan, mengolah, dan menyampaikan informasi dengan menggunakan segala jenis saluran yang tersedia."

Implementasi pada UUD'45 Ps. 28F perubahan kedua yang diresmikan pada bulan Agustus 2020 dan juga Ps. 19 Deklarasi Universal HAM ini bisa dilihat dari jaringan yang dapat dijangkau oleh media sosial, dimana setiap orang bisa memutuskan untuk bergabung atau tidak bergabung secara bebas untuk menyepakati sesuatu ataupun tidak menyepakati sama sekali mengenai pemberitaan yang ditulis, misalnya dalam berita singkat atau artikel; atau diucapkan secara lisan baik yang berbentuk rekaman suara ataupun video yang dilakukan melalui beberapa platform media sosial contohnya WA group, Youtube, Twitter, FB, $I G$, dan lainnya.

Kebebasan berekspresi disebut juga kebebasan berbicara. Ke-2 konsep ini sama. Kebebasan berekspresi sangat berkaitan kuat dengan kebebasan pers. Kebebasan berekspresi mengandung kebebasan secara langsung, cetak, audiovisual, seekspresi budaya, dan artistic politik. Sedangkan pers difokuskan pada media cetak dan penyiaran, yang berhubungan dengan jurnalisme dan jurnalis.

Kebebasan berekspresi juga disebut rumit. Karena kebebasan berekspresi tidak absolut juga diikuti tanggung jawab tertentu, "wajib mematuhi sejumlah pembatasan, sejauh pembatasan tersebut ditetapkan oleh hukum dan diperlukan". Menjadi rumit karena "hak ini melindungi hak pembicara sekaligus hak pendengar". Kedua hak ini bisa bertolak belakang dan sulit untuk diselaraskan. Hak yang sering mengalami perbedaan yang tidak mudah menemukan keseimbangan secara tepat antara kehormatan, keselamatan dan privasi. Batasan tersebut dibuat setelah terjadi ketegangan seperti demikian.

Berdasarkan UU No. 19 Ps.1 Thn 2016 tentang perubahan UU ITE No. 11 Thn 2008, yang dimaksud dengan Informasi Elektronik yaitu sebuah atau lebih data elektronik, dan tidak terbatas pada tulisan, suara, gambar, peta, rancangan, foto, electronic data interchange (EDI), surat elektronik (electronic mail), telegram, teleks, telecopy atau sejenisnya, huruf, tanda, angka, Kode Akses, simbol, atau perforasi yang telah diolah yang memiliki arti serta dapat dipahami oleh orang lain. Transaksi elektronik yaitu perbuatan hukum menggunakan komputer, internet dan lainnya.

Adapun UU ITE terdapat informasi transaksi elektronik, atau teknologi informasi secara umum. UU ini memiliki yuridiksi yang berlaku bagi tiap orang yang melakukan pelanggaran, dalam UU ini. Baik yang berada di dalam atau luar wilayah hukum Indonesia, yang berakibat merugikan kepentingan Indonesia. 


\section{Permasalahan}

Berdasarkan yang sudah dipaparkan dan diuraikan dalam latar belakang, pelanggaran UU ITE yang sering terjadi, yaitu :

1. Bagaimana implementasi UU ITE agar bisa memiliki koridor pembatas yang jelas bagi masyarakat?

2. Bagaimana seharusnya masyarakat bersikap yang tepat agar bisa mengekspresikan diri tanpa melanggar UU ITE?

\section{METODE PENELITIAN}

Dengan memakai metode penelitian hukum normatif, maka cara menganalisis permasalahan berdasarkan data sekunder yang menyatakan pada peraturan per UU, serta literatur hukum. Menggunakan panduan kepustakaan dan dilakukan dengan pengumpulan bahan hukum, berdasarkan bahan hukum primer dan bahan hukum sekunder. Bahan hukum primer yaitu peraturan perundang-undangan UU No. 39 Thn 1999 HAM serta UU No. 19 Thn 2016 UU ITE, sedangkan bahan hukum sekunder merupakan literatur hukum seperti buku, makalah, jurnal dan artikel yang berhubungan dengan pokok permasalahan yang menjadi topik dalam UU ITE. Dengan menggunakan pendekatan perundang-undangan (statute approach) setelah ditelaah ke semua peraturan UU yang berhubungan dengan isu hukum terkini.

\section{HASIL DAN PEMBAHASAN}

Masyarakat di Indonesia adalah masyarakat yang majemuk, terdiri dari multikultural yang mempunyai berbagai ragam perspektif. Masyarakat Indonesia juga bersifat komunal yaitu kebersamaan dalam kelompok. Masyarakat komunal mempunyai rasa ingin tahu yang sangat besar terhadap orang lain, untuk orang yang berbeda maka mereka akan membentuknya dengan menggunjingkan orang lain agar menjadi sama, orang baru harus hormat kepada orang lama dengan cara memberikan perintah baik secara resmi ataupun tidak.

Dikarenakan keberagaman kultural dan sifat komunal tersebut, maka perlu ada nya pengendalian sosial. Pengendalian sosial ialah cara untuk mengajak dan mencegah masyarakat agar tidak melakukan pennyimpangan sosial dan berperilaku sesuai norma yang ada. Ditinjau dari sifatnya pengendalian sosial terdiri dari, tindakan preventif untuk menghentikan perbuatan yang tidak sesuai dengan peraturan yang berlaku, tindakan represif untuk membentuk kembali keselarasan yang pernah terusik karena adanya pelanggaran, melalui pemberian hukuman dan tindakan kuratif dilakukan pada saat terjadi penyimpangan sosial.

Ditinjau dari cara atau perlakuannya pengendalian sosial terdiri dari tindakan persuasif dengan cara melakukan pendekatan melalui ucapan untuk membujuk masyarakat agar menaati norma yang berlaku dan tindakan koersif dengan cara memberikan hukuman. Bentuk Pengendalian sosial yaitu gosip, teguran, sanksi/hukuman, Pendidikan, agama. Pelanggaran berekspresi "yang tidak pantas" sering diutarakan lewat medsos. Berikut adalah beberapa informasi yang Penulis dapatkan untuk ditelaah berkenaan yang terkait dengan pelanggaran UU ITE : 


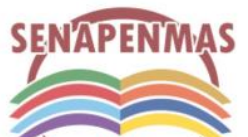

2021
Seminar Nasional Hasil Penelitian dan Pengabdian Kepada Masyarakat 2021

Pengembangan Ekonomi Bangsa Melalui Inovasi Digital Hasil Penelitian dan Pengabdian Kepada Masyarakat Jakarta, 21 Oktober 2021

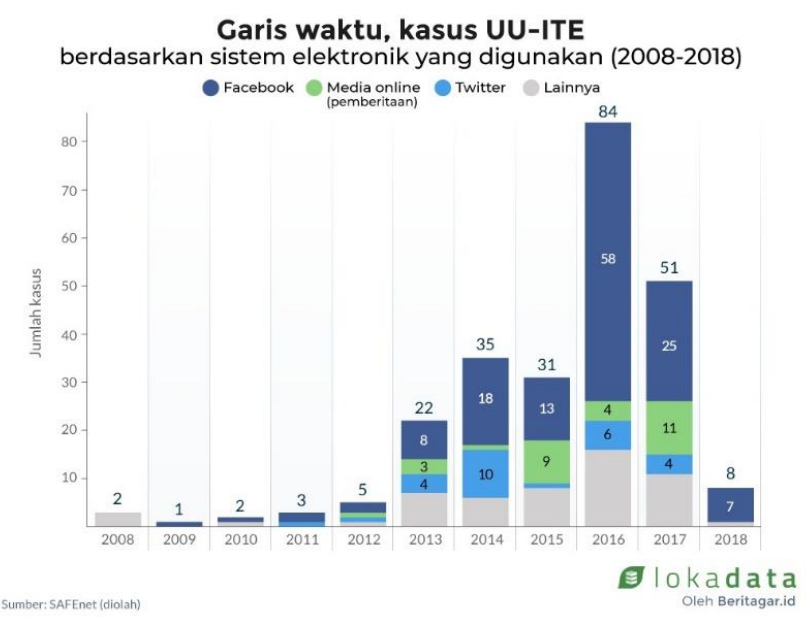

Gambar 1. Garis Waktu Kasus UU ITE Berdasarkan Sistem Elektronik Yang Digunakan Sumber tabel : lokadata oleh Beritagar.id

Berdasarkan tabel tersebut, dari rentang waktu tahun 2008 - 2018 dapat dilihat media sosial yang paling banyak digunakan dalam berekspresi yang berujung pada pelanggaran UU ITE adalah :

1. Facebook, memegang jumlah terbanyak di antara media sosial lainnya,

2. Media online (pemberitaan), seperti website-website pemberitaan (contoh : Liputan6.com, Kompas.com, CNN, dan lain-lain),

3. Twitter, dan

4. Lainnya, seperti : Whatsapp, Youtube, blog, email, SMS, petisi online, dan lainnya.

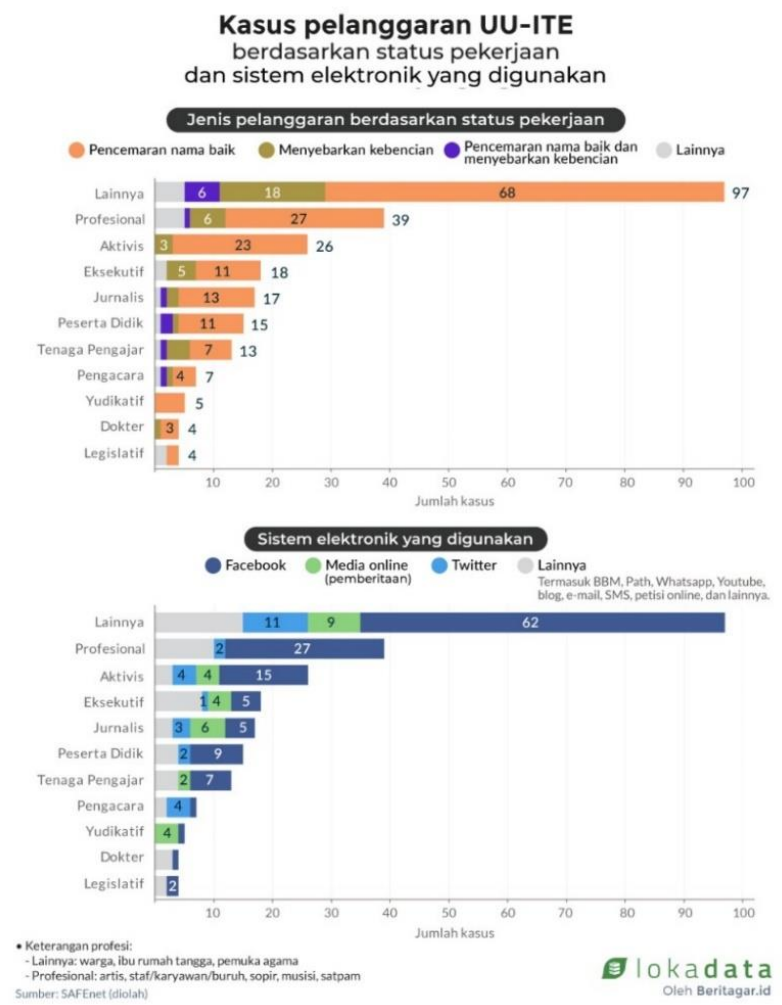

Gambar 2. Kasus Pelanggaran UU ITE Berdasarkan Status Pekerjaan dan

Sistem Elektronik Yang Digunakan

Sumber tabel : lokadata oleh Beritagar.id 
Berdasarkan data yang ditemukan, dapat dilihat bahwa pelanggaran UU ITE yang paling banyak terjadi adalah pada kasus :

1. Pencemaran nama baik, dijerat Ps. 27 (3) yaitu "Setiap Orang dengan sengaja dan tanpa hak mendistribusikan dan/atau mentransmisikan dan/atau membuat dapat diaksesnya Informasi Elektronik dan/atau Dokumen Elektronik yang memiliki muatan penghinaan dan/atau pencemaran nama baik",

2. Ujaran kebencian, terjerat Ps. 28 (2) jo. Ps. 45A (2) yaitu "Setiap Orang dengan sengaja dan tanpa hak menyebarkan informasi yang ditujukan untuk menimbulkan rasa kebencian atau permusuhan individu dan/atau kelompok masyarakat tertentu berdasarkan atas suku, agama, ras, dan antargolongan (SARA) sebagaimana dimaksud dalam Pasal 28 (2) dipidana dengan pidana penjara paling lama 6 (enam) tahun dan/atau denda paling banyak Rp1.000.000.000,00 (satu miliar rupiah)",

3. Pencemaran nama baik dan menyebarkan kebencian, dijerat dengan 2 pasal sekaligus, yaitu Ps. 27 (3) dan Ps. 28 ayat (2) jo. Ps. 45A (2) UU ITE,

4. Lainnya, seperti :

4.1. Pornografi dengan jeratan Ps. 27 (1) menyatakan "Setiap Orang dengan sengaja dan tanpa hak mendistribusikan dan/atau mentransmisikan dan/atau membuat dapat diaksesnya Informasi Elektronik dan/atau Dokumen Elektronik yang memiliki muatan yang melanggar kesusilaan",

4.2. Berjudi dengan jeratan Ps. 27 (2) yang menyatakan "Setiap Orang dengan sengaja dan tanpa hak mendistribusikan dan/atau mentransmisikan dan/atau membuat dapat diaksesnya Informasi Elektronik dan/atau Dokumen Elektronik yang memiliki muatan perjudian",

4.3. Berita bohong / hoax dijerat Ps. 28 (2) jo. Ps. 45A (2) UU ITE, dan lainnya.

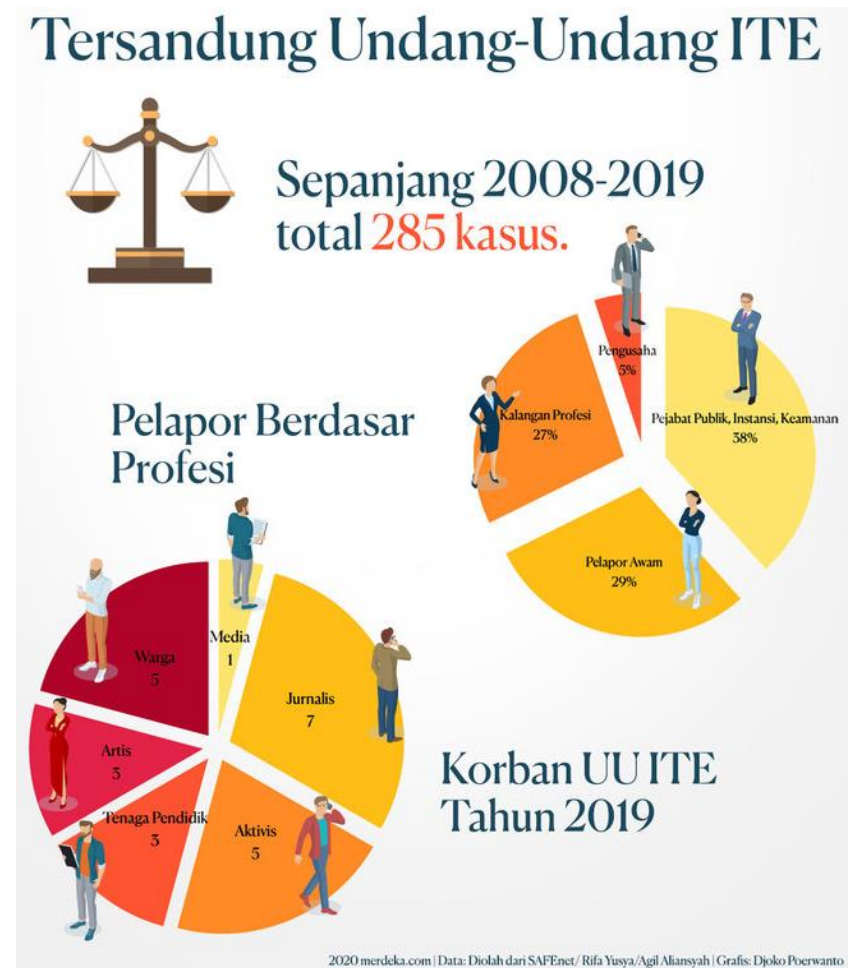

Tabel 3. Kasus Pelanggaran UU ITE Sepanjang Tahun 2008-2019

Sumber tabel : merdeka.com 
Berdasarkan data berikut, sepanjang tahun 2008-2019 telah terjadi sebanyak 285 kasus pelanggaran UU ITE, dengan pihak Pelapor diantaranya berprofesi berikut :

1. Pejabat publik, instansi dan keamanan, dengan jumlah kasus sebesar $38 \%$,

2. Pelapor awam, dengan jumlah kasus sebesar $29 \%$,

3. Kalangan professional, dengan jumlah kasus sebesar $27 \%$,

4. Pengusaha, dengan jumlah kasus sebesar 5\%.

Sementara dari tabel tersebut juga bisa dilihat jumlah korban UU ITE Tahun 2019 terdiri dari :

1. Jurnalis sebanyak 7 orang,

2. Aktivis sebanyak 5 orang,

3. Warga sebanyak 5 orang,

4. Tenaga pendidik sebanyak 3 orang,

5. Artis sebanyak 3 orang, dan

6. Media sebanyak 1 orang.

Pada Surat Keputusan Bersama (SKB) UU ITE No. 19 Thn 2016, dijelaskan mengenai pedoman implementasi terkait dengan pasal-pasal pada UU ITE No. 19 Thn 2016 yang sering menjadi larangan di masyarakat dalam melakukan kebebasan berekspresi di media sosial, diantaranya memuat mengenai :

1. Pelanggaran tentang pornografi (Ps. 27 (1) UU ITE), dijelaskan mengenai makna frasa "muatan (konten) melanggar kesusilaan" dalam pengertian luas dan sempit, pornografi seperti apa yang melanggar kesusilaan, fokus perbuatan yang dilarang yang bisa menimbulkan pelanggaran mengenai pornografi, dan bagaimana suatu tindakan disebut melakukan perbuatan "membuat dapat diaksesnya" pornografi.

2. Pelanggaran mengenai perjudian (Ps. 27 (2) UU ITE), dijelaskan tentang titik berat perbuatan yang mengarah ke perjudian, jenis konten apa saja yang termasuk dalam pelanggaran mengenai perjudian, dan penyebarannya.

3. Pencemaran nama baik (Ps. 27 (3) UU ITE), dijelaskan tentang pengertian muatan (konten) dalam kategori perbuatan yang mengarah pada pencemaran nama baik.

4. Pelanggaran mengenai pemerasan dan pengancaman (Ps. 27 (4) UU ITE), dijelaskan mengenai perbuatan seperti apa yang masuk dalam kategori pemerasan dan pengancaman.

5. Pelanggaran tentang kebohongan atau hoax (Ps. 28 (1) UU ITE), dijelaskan mengenai kategori tindakan pelanggaran terkait berita bohong atau hoax.

6. Pelanggaran mengenai kebencian atau permusuhan pribadi serta kelompok tertentu berdasarkan SARA (Ps. 28 (2) UU ITE), dijelaskan mengenai perbuatan seperti apa yang bisa mengarah pada pelanggaran ini dan jenis informasi seperti apa yang bisa dikategorikan sebagai pelanggaran ini.

7. Pelanggaran mengenai pengancaman (kekerasan dan menakut-nakuti), yang ditujukan secara pribadi (Ps. 29 UU ITE), dijelaskan mengenai perbuatan serta bentuk pelanggaran yang mengandung ancaman kekerasan untuk menakut-nakuti seseorang.

8. Pelanggaran mengenai perbuatan pelanggaran yang disebutkan pada Ps. 27 sampai Ps. 34 UU ITE No. 19 Thn 2016 yang berakibat merugikan orang lain (Ps. 36 UU ITE), dijelaskan mengenai kerugian-kerugian seperti apa sajakah yang timbul akibat pelanggaran-pelanggaran yang terdapat pada Ps. 27 sampai Ps. 34 UU ITE No. 19 Tahun 2016.

Dengan diketahuinya implementasi-implementasi terkait pelanggaran-pelanggaran UU ITE ini dapat dijadikan koridor pembatas bagi masyarakat dalam berekspresi di media sosial. Masyarakat harus tahu jelas batasan-batasan dalam berucap dan bertindak di media sosial. Sehingga dengan demikian masyarakat dapat menjadi lebih bijak dalam menggunakan media sosial. 


\section{KESIMPULAN \\ Kesimpulan}

Dikarenakan masyarakat Indonesia terdiri dari multikultural dan komunal, dimana mempunyai rasa ingin tahu yang sangat besar, sering menggunjingkan orang lain yang terlihat berbeda dengan kelompoknya, dan memiliki rasa senioritas yang tinggi menyebabkan perlunya pengendalian sosial.

Pengendalian sosial yang tepat dengan karakteristik masyarakat Indonesia adalah dengan cara preventif dan persuasif, dimana dalam hal terjadinya pelanggaran UU ITE pemerintah harus bersikap persuasif dengan melalui pendekatan kepada masyarakat dengan cara menyampaikan informasi ke publik melalui media masa baik cetak maupun elektronik, dan juga dengan cara preventif dalam bentuk edukasi bahwa tindakan - tindakan yang menyebabkan pelanggaran UU ITE memiliki sanksi hukum yang berlaku.

Kebebasan berekspresi juga bisa dilakukan oleh semua orang, baik dengan profesi apapun, di media sosial apapun, yang sering kali dikarenakan ketidaktahuan masyarakat mengenai apa itu UU ITE, dan juga ketidaktahuan batasan-batasan yang tercantum di UU ITE, serta ketidakmengertian mengenai implementasinya maka kerap kali kita jumpai kegiatan mengekspresikan diri yang berujung pada pelanggaran UU ITE.

\section{Saran}

Belajar dari kasus pelanggaran-pelanggaran yang sudah sering terjadi, maka perlu diadakan sosialisasi pedoman implementasi mengenai UU ITE kepada masyarakat, agar masyarakat memahami secara mendetail mengenai tindakan-tindakan apa saja yang bisa mengarah pada pelanggaran UU ITE, dan juga agar masyarakat menjadi paham batasan-batasan yang tidak boleh dilanggar.

Pelatihan atau sosialisasi mengenai bagaimana 'etika' kebebasan berekspresi di ruang publik, khususnya di medsos seperti $F B$, WA, Youtube, dan lainnya, menjadi sesuatu yang penting untuk menyampaikan pemahaman yang benar dalam berekspresi. Dan juga sosialisasi mengenai batasan-batasan apa saja yang diatur di dalam UU ITE bisa lebih sering disosialisasikan kepada masyarakat, sehingga masyarakat menjadi "melek hukum" dan bisa lebih bertanggung jawab terhadap ucapan dan tindakannya.

Pemerintah sebaiknya melakukan pendekatan kepada masyarakat dengan cara bekerjasama dengan tokoh masyarakat, public figure, pemuka agama agar bisa memberikan pengaruh yang positif dalam mengekspresikan kebebasan di media sosial.

\section{Ucapan Terima Kasih (Acknowledgement)}

Penulis berterimakasih kepada keluarga yang sangat mendukung, sehingga makalah ini bisa diselesaikan dengan baik.

\section{REFERENSI}

\section{Buku}

Ishaq. 2017. Metode Penelitian Hukum Dan Penulisan Skripsi, Tesis, Serta Disertasi. Alfabeta. Bandung.

Soerjono Soekanto, dan Sri Mamudji. 2021. Penelitian Hukum Normatif Suatu Tinjauan Singkat

hal. 13-14. Raja Grafindo Persada. Jakarta.

Sugiyono. 2009. Metode Penelitian Kuantitatif, Kualitatif dan R\&D. Alfabeta. Bandung.

Sutarjo, Adisusila. 2013. Pembelajaran Nilai-Nilai Karakter hal. 21. PT. Raja Grafindo Persada. Jakarta.

The United Nations Educational, Scientific and Cultural Organization (UNESCO). Toolkit 
Kebebasan Berekspresi Bagi Aktivis Informasi. Perancis. Jakarta, 21 Oktober 2021

\section{Jurnal}

Rahmawati, Muslichatun dan Marizal. 2021. "Kebebasan Berpendapat Terhadap Pemerintah Melalui Media Sosial Dalam Perspektif UU ITE”. Pranata Hukum Vol. 3 No. 1 Februari 2021.

Arsyad, Nadjib. 2011. "Kebebasan Berpendapat Pada Media Jejaring Sosial - Analisis Wacana Facebook Dari Jejaring Pertemanan Menuju Jejaring Perlawanan”. Jurnal komunikasi KAREBA Vol. 1 No. 1 Januari-Maret 2011.

Arifin, Widyowati dan Hernawaty. 2017. "Freedom Of Expression Di Media Sosial Bagi Remaja Secara Kreatif Dan Bertanggung Jawab : Bagi Siswa SMA Al-Ma'some Rancaekek dan SMA Muhammadiyah Pangandaran”. Jurnal Pengabdian Kepada Masyarakat ISSN 14105675 Vol. 1 No. 5 : 332-337.

Izzah, Ismatul. "Media Sosial, Antara Peluang Dan Ancaman Dalam Pembentukan Karekter Didik Anak Ditinjau Dari Sudut Pandang Pendidikan Islam". Melalui website : https://ejournal.inzah.ac.id/index.php/attalim/article/download/63/36

Purbohastuti, Arum Wahyuni. "Efektivitas Media Sosial Sebagai Media Promosi”. Tirtayasa Ekonomika Vol. 12 No. 2 Oktober 2017.

Syahri, Akhmad Syafrudin. "Kebebasan Berpendapat Melalui Media Baru Dalam BayangBayang UU ITE”. Akademi Komunikasi Bina Sarana Informatika.

Basri, H. (2014). "Using qualitative research in accounting and management studies: not a new agenda”. Journal of US-China Public Administration. October 2014. Vol.11, No.10, 831838. DOI: $10.17265 / 1548-6591 / 2014.10 .003$.

\section{Regulasi}

Indonesia.UUD 1945. Lembaran Negara No 75 thn 1959.

Indonesia.UUD 1945 Perubahan ke-2, Agustus 2020.

Indonesia.UU No. 39 Thn 1999 tentang HAM. Tambahan Lembaran Negara RI No. 3886.

Indonesia.Deklarasi Universal HAM. Diterima Dan Diumumkan Oleh Majelis Umum PBB Tgl 10

Desember 1948 Melalui Resolusi 217A (III).

Indonesia.UU No. 11 Thn 2008 jo. UU No. 19 Thn 2016 Tentang Informasi Dan Transaksi

Elektronik. Tambahan Lembaran Negara RI No. 4843.

Indonesia.Surat Keputusan Bersama (SKB) UU ITE No. 19 Thn 2016.

\section{Skripsi}

Multikulturalisme masyarakat perkotaan (Studi Tentang Integrasi Sosial Antar Etnis Di Kelurahan

Nyamplungan, Kecamatan Pabean Cantikan, Kota Surabaya). 2018. Universitas Airlangga.

\section{Website}

Ebta Setiawan. Kamus Besar Bahasa Indonesia Online. 2021-2021. https://kbbi.web.id/. Diakses tanggal 01 Oktober 2021.

Yoni Andrianto. 06 Maret 2019. "Memahami Metode Penelitian Kualitatif". https://www.djkn.kemenkeu.go.id/artikel/baca/12773/Memahami-Metode-PenelitianKualitatif.html. Diakses tanggal 01 Oktober 2021.

Rifa Yusya Adilah. 22 Oktober 2020. "Terjerat Pasal Karet UU ITE". https://m.merdeka.com/khas/terjerat-pasal-karet-uu-ite-midreport.html. Diakses tanggal 01 Oktober 2021. 
Ari Welianto (ed). 17 April 2020. "Pengendalian Sosial : Pengertian, Ciri dan Caranya". https://www.kompas.com/skola/read/2020/04/17/203000769/pengendalian-sosial-pengertian-ciri-dan-caranya. Diakses tanggal 01 Oktober 2021.

\section{Artikel}

https://artikelsiana.com/pengertian-media-sosial-fungsi/

https://beritagar.id/artikel/berita/ibu-rumah-tangga-dan-facebook-jerat-empuk-uu-ite 